\title{
Peran Orang Tua dalam Pencegahan Karies Gigi pada Anak Pra Sekolah (3-5 Tahun) di TK Aisyiyah 2 Pekanbaru
}

\author{
Wiwik Norlita, Isnaniar, Isnaniar, Mochammad Hidayat \\ Faculty of Mathematics, Natural Sciences and Health, Universitas Muhammadiyah Riau, Indonesia \\ Correspondence Email: wiwiknorlita@umri.ac.id
}

\begin{abstract}
Dental caries is a hard tissue disease caused by bacterial activity. Dental caries can occur in any child which can occur on a tooth surface and can extend to the deeper part of the tooth. The purpose of this study was to determine the role of parents in the prevention of dental caries in pre-school children at TK Aisyiyah 2 Pekanbaru. The type of research used is descriptive with total sampling techniques, totaling 64 respondents. Data collection tools using a questionnaire and data analysis used is univariate. The results of the study which was carried at TK Aisyiyah 2 Pekanbaru, the majority of parents' roles in preventing caries in pre-school age children were in the bad category of $62.5 \%$. There are 40 respondents who have a bad role in preventing the occurrence of dental caries in pre-school children. The results of this study are expected to the parents to be able to implement a clean and healthy lifestyle to prevent dental caries in pre-school children
\end{abstract}

Keywords: Role, Parents, Prevention, Dental Caries

\begin{abstract}
Abstrak
Karies gigi merupakan suatu penyakit jaringan keras gigi yang disebabkan oleh aktivitas bakteri. Karies gigi dapat terjadi pada setiap anak yang dapat timbul pada suatu permukaan gigi dan dapat meluas kebagian yang lebih dalam dari gigi. Tujuan penelitian ini adalah untuk mengetahui peran orang tua dalam pencegahan karies gigi pad anak usia pra sekolah di TK Aisyiyah 2 Pekanbaru. Jenis penelitian yang digunakan adalah deskiptif dengan tehnik pengambilan sampel total sampling yang berjumlah 64 responden. Alat pengumpulan data menggunakan kuesioner dan Analisa Data yang digunakan adalah univariate. Hasil Penelitian yang telah dilaksanakan di TK Aisyiyah 2 Pekanbaru diperoleh hasil mayoritas peran orangtua terhadap pencegahan karies pada anak usia pra sekolah pada kategori tidak baik sebesar $62.5 \%$. terdapat 40 responden yang memiliki peran yang tidak baik dalam melakukan pencegahan terjadinya karies gigi pada anak usia pra sekolah. Hasil penelitian tersebut diharapkan kepada pihak orang tua untuk dapat menerapkan perilaku hidup bersih dan sehat untuk mencegah terjadinya karies gigi pada anak pra sekolah
\end{abstract} Kata Kunci : Peran, Orang Tua, Pencegahan, Karies Gigi.

Received: 15 September 2020, Accepted : October 2020 - Jurnal Photon Vol.11 No.1

DOI : https://doi.org/10.37859/jp.v11i1.2145

PHOTON is licensed under a Creative Commons Attribution-ShareAlike 4.0 International License 


\section{Introduction}

Karies merupakan suatu keadaan kerusakan yang terjadi pada gigi susu secara luas dan berkembang dengan cepat. Karies dapat disebabkan karena perilaku menjaga kebersihan mulut anak yang kurang, karena anak usia antara 3-6 tahun atau anak usia pra sekolah masih kurang mengetahui dan memelihara kebersihan gigi dan mulut (Depkes, 1999). Selain itu anak-anak pada umumnya senang makan makanan yang manis dan jarang membersihkannya, sehingga gigi-giginya banyak mengalami karies (Zein, 2005 dalam Listriana, 2011). Angka kejadian karies gigi pada anak usia pra sekolah dasar cukup tinggi, (WHO) pada tahun 2003, menyatakan angka kejadian karies pada anak sebesar 60-90 persen. Data WHO menunjukkan rata-rata pengalaman karies anak usia 12 tahun berkisar 2,4 persen. Hasil Riset Kesehatan Dasar (RISKESDAS) tahun 2013 dari Departemen Kesehatan menunjukkan sebanyak 25,9 penduduk Indonesia mempunyai masalah gigi dan mulut. Data terbaru dari Oral Health Media Centrepada April 2012, memperlihatkan sebanyak 60-90 persen anak usia sekolah dan hampir semua orang dewasa diseluruh dunia memiliki permasalahan gigi (Riskesdas, 2013).

Menurut National Institution of Health di Amerika Serikat karies gigi menjadi penyakit kronis yang paling sering diderita anak umur 5-17 tahun, yang kasusnya lima kali lebih banyak dibandingkan penyakit asma dan tujuh kali dibandingkan dengan demam akibat alergi. Jika tidak diobati karies gigi dapat menyebabkan sakit, gangguan penyerapan makanan, mempengaruhi pertumbuhan tubuh anak dan hilangnya waktu sekolah. Menurut data dari pengurus besar PDGI (Persatuan Dokter Gigi Indonesia) menyebutkan bahwa sedikitnya 89\% penderita gigi berlubang adalah anak-anak usia dibawah 12 tahun (Sariningsih, 2012).

Berdasarkan hasil riset Profil Kesehatan Riau 2013. Murid SD/MI diperiksa dan memerlukan perawatan tahun 2013 sebanyak 32.125 anak. Cakupan perawatan gigi dan mulut murid SD/MI di Provinsi Riau tahun 2013 sebesar 57,4\% mengalami penurunan bila dibanding tahun 2012 (51,8\%). Program kesehatan gigiterutama dalam perawatan gigi dan mulut terutama bagi murid SD/MI harus mendapatperhatian khusus dalam rangka menjaga kesehatan gigi dan mulut anak sekolah (Roza dkk, 2018). Keberhasilan perawatan gigi anak tidak lepas dari kerja sama antara beberapa pihak, dalam hal ini diperlukan peran orang tua. Adapun peranan orang tua terhadap keberhasilan perawatan gigi anak yaitu: orang tua sebagai teladan yang akan di jadikan oleh seorang anak sebagai panutan yang akan memberikan contoh yang baik terhadap perawatan gigi anak, orang tua berperan sebagai kontroler untuk tetap mengawasi anaknya untuk tetap memperhatikan kebersihan giginya, orang tua sebagai figur yang dapat memberikan pemahaman yang lebih baik kepada anak tentang apa yang baik untuk perawatan gigi anak dan orang tua sebagai motivator yang akan selalu memberikan bimbingan kepada seorang anak untuk tetap memperhatikan kebersihan giginya (Sunanti DA, 2012).

Received: 15 September 2020, Accepted : October 2020 - Jurnal Photon Vol.11 No.1

DOI : https://doi.org/10.37859/jp.v11i1.2145

PHOTON is licensed under a Creative Commons Attribution-ShareAlike 4.0 International License 
Berdasarkan survei awal yang di lakukan kepada 10 responden di dapatkan data sebagai berikut , 60 persen anak di TK Aisyiyah 2 Pekanbaru tidak ada masalah pada gigi, 50 persen orang tua mengajarkan anak untuk mengosok gigi sesuda makan dan 50 persen orang tua melarang anak untuk makan-makanan yang manismanis, ada 60 persen anak menyikat gigi, 100 persen orang tua memberikan contoh cara menyikat gigi dengan benar, 60 persen orang tua memberi tahu anak untuk mengosok gigi setelah sarapan dan selum tidur dan 60 persen pernah mendapat informasi tentang karies gigi (gigi berlubang/gigi rusak) dari media elektronik (radio, televisi, internet), sedangkan 40 persen mengalami kerusakan gigi dan tidak pernah mendapatkan informasi tentang karies gigi.

\section{A. Konsep dasar peran Orang tua}

1. Pengertian Peran orang tua

Peran orang tua merupakan perilaku orang tua yaitu ayah-ibu dalam mendidik anak dan sebagai panutan utama seorang anak yang perilakunya akan ditiru dan diikuti oleh anak (W.J.S Poerwadarminta, 2003). Peran serta orang tua sangat di perlukan di dalam membimbing, memberikan pengertian, megingtkan, dan menyediakan fasilitas kepada anak agar anak dapat memelihara kebersihan gigi dan mulutnya. Selain itu orang tua jugamempunyai peran yang cukup besar di dalam mencegah terjadinya akumulasi plak dan terjadinya karies pada anak. Pengetahuan orang tua sangat penting dalam mendasari terbentuknya perilaku yang mendukung kebersihan gigi dan mulut anak. Pengetahuan tersebut diperoleh dari alami maupun secara terencana yaitu melalui proses pendidikan. Orang tua dengan pengetahuan rendah mengenai kesehatan gigi dan mulut merupakan faktor predisposisi dari perilaku yang tidak mendukung kesehatan gigi dan mulut (Riyanti E, 2012).

Peran aktif orangtua ini diperlukan terutama pada usia prasekolah. Anak usia prasekolah khususnya anak usia 4-6 tahun memerlukan bantuan orangtua dalam menyikat gigi walaupun anak mampu untuk memanipulasi pergerakan sikat gigi mereka. Anak belajar menyikat gigi dibantu ibunya dari belakang menggunakan sikat gigi anak. Anak diajari berkumur dengan cara mencontoh ibunya berkumur dengan menggunakan air matang. Bila anak sudah berumur 2 tahun, semua gigi sulung sudah mulai tumbuh, anak diharapkan mulai menyikat gigi sendiri dengan pengawasan orangtua. Menyikat gigi 3 kali sehari sesudah makan pagi, sesudah makan siang dan sebelum tidur malam hari. Sesudah makan biasakan berkumur dengan air putih. Setelah anak bisa berkomunikasi dengan orangtuanya dengan lancar, kirakira umur 3 tahun anak diharapkan bisa menyikat giginya sendiri dengan pasta gigi yang mengandung fluoride kemudian bisa berkumur-kumur dengan air dan orangtua membiasakan anak agar tidak mengkonsumsi makanan yang mengandung bahan pemanis, pewarna, dan pengawet yang dapat memicu

Received: 15 September 2020, Accepted : October 2020 - Jurnal Photon Vol.11 No.1

DOI : https://doi.org/10.37859/jp.v11i1.2145

PHOTON is licensed under a Creative Commons Attribution-ShareAlike 4.0 International License 
terjadinya karies gigi contohnya sejak anak usia 2 tahun orangtua mengenalkan bermacam-macam buah-buahan maupun sayur-sayuran (Sariningsih, 2012).

\section{B. Pengertian Anak Usia Pra Sekolah}

Menurut Wong (2008), dalam Murdani (2016), anak usia prasekolah termasuk dalam masa kanak-kanak awal yang terdiri dari usia 3 sampai 5 tahun.

1. Klasifikasi Usia Anak

Klasifikasi usia anak menurut Betz, Sowden ( 2009), dalam Murdani (2016) adalah sebagai berikut :
a. Usia bayi ( 0-1 tahun )
b. Usia toddler (1-3 tahun )
c. Usia pra sekolah ( 3-5 tahun )
d. Usia sekolah ( $>5$ tahun )

\section{Pengertian Karies Gigi}

Menurut Riyanti, (2015) Karies gigi merupakan suatu penyakit jaringan keras gigi yaitu email, dentin dan sementum yang disebabkan oleh aktivitas bakteri dalam suatu karbohidrat yang difermentasikan. Definisi karies itu sendiri adalah penyakit jaringan gigi yang ditandai dengan kerusakan jaringan, dimulai dari permukaan gigi meluas kearah pulpa. Karies gigi dapat terjadi pada setiap orang yang dapat timbul pada suatu permukaan gigi dan dapat meluas kebagian yang lebih dalam dari gigi
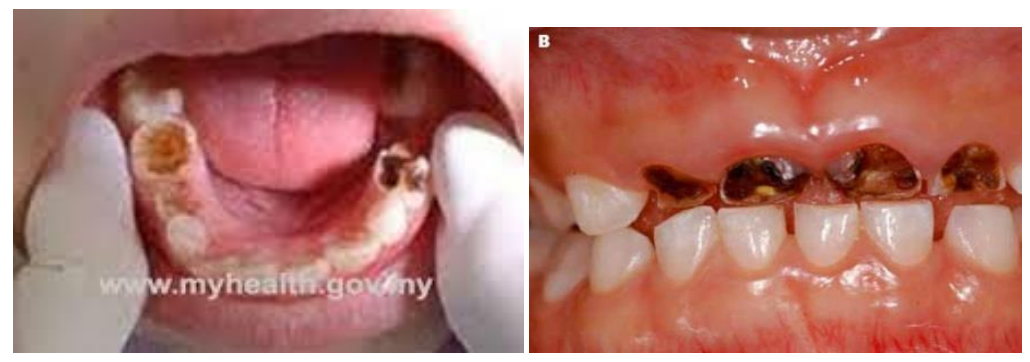

Gambar 1. Karies Gigi (Sumber : Hasni (2014)

1. Pencegahan karies dentis

Pencegahan karies gigi dapat dilakukan dalam tiga tahap yaitu yaitu tahap pencegahan primer sekunder dan tersier.Pencegaha primer bertujuan untuk mencegah terjadinya penyakit dan mempertahankan keseimbangan fisiologis. Pencegahan sekunder bertujuan untuk mendeteksi karies secara dini dan intervensi untuk mencegah berlanjutnya penyakit. Tersier di tujukan untuk mencegah meluasnya penyakit yang akan menyebabkan hilangnya fungsi pengunyahan dan gigi.

Received: 15 September 2020, Accepted : October 2020 - Jurnal Photon Vol.11 No.1

DOI : https://doi.org/10.37859/jp.v11i1.2145

PHOTON is licensed under a Creative Commons Attribution-ShareAlike 4.0 International License 
a. Pencegahan Primer (Drummond)

Pencegahan primer dapat dilakukan dengan berbagai cara, yaitu:

1) Modifikasi Diet

Mencegahterjadinyakariesgigimakaperludilakukanmodifikasidiet melaluiberbagaicara, yaitu:

a) Memperbanyak memakan makanan kari ostatik seperti lemak, protein dan flour. Lemak dapat meningkatkan $\mathrm{pH}$ saliva setelah mengkonsumsi karbohidrat. Lemak harus dikonsumsi sebelum memakan makanan yang manis. Protein meningkatkan urea saliva yang dapat menetralisir asam. Mengkonsumsi makanan tinggi protein setelah makan karbohidrat dapat mengembalikan pH menjadi 7 dengan cepat. Flour secara alami terdapat dalam jumlah yang kecil pada teh dan makanan laut. Makanan yang mengandung protein seperti tahu, tempe, daging, ikan, telur dan kacang-kacangan.

b) Mengganti gula, Gula sintetik seperti saccharine dan aspartame serta gula alcohol (gula jagung) banyak digunakan pada makanan untuk mengurangi karies.

c) Mengurangi mengkonsumsi makanan yang manis dan asam.

d) Mengurangi konsumsi snack yang mengandung karbohidrat sebelum tidur.

e) Mengkombinasikan makanan seperti memakan makanan manis setelah makan protein dan lemak atau setelah konsumsi keju setelah memakan makanan yang manis.

f) Kombinasikan makanan mentah dan renyah yang dapat menstimulasi saliva dengan makanan yang dimasak.

g) Makan-makanan yang mengandung kalsium vitamin $C$, vitamin $\mathrm{D}$ berguna untuk memperkuat gigi. Jenis makanan yang mengandung bahan tersebut antara lain susu telur dan buah-buahan.

h) Makan sayur-sayuran karena sayuran mempunyai kandungan nitrat. Bahan tersebut dapat menghambat kerja bakteri seperti bayam dan selada.

i) Makanan yang mempunyai daya pembersih terdapat pada makanan berserat. Makanan terdapat pada apel, jeruk, seledri, jambu air.Makan ini baik dimakan sesudah makan atau diantara waktu makan.

j) Buah-buahan yang asam dapat menstimulasi produk sissliva.

k) Membatasi meminum-minuman yang manis.

Received: 15 September 2020, Accepted : October 2020 - Jurnal Photon Vol.11 No.1

DOI : https://doi.org/10.37859/jp.v11i1.2145

PHOTON is licensed under a Creative Commons Attribution-ShareAlike 4.0 International License 


\section{2) Pemakaian Flour}

Flour berfungsi menghambat enzim pembentukan asam oleh bakteri, menghambat kerusakan email lebih lanjut, serta membantu remineralisasi pada lesi awal karies. Flour dapat diberikan dalam bentuk flouridasi air minum, pasta gigi, obat kumur, dan tablet flour.

3) Pit dan fissure sealant yaitu penutupan pit dan fissure yang dalam yang beresiko terhadap karies.

a) Pengendalian Plak

Pengendalian plak dapat dilakukan dengan tindakan secara mekanis yaitu dengan penyikatan gigi dan penggunaan alat-alat bantu lain seperti benang gigi, tusuk gigi dan sikat interdental serta tindakan secara kimiawi yaitu dengan menggunakan antibiotic dan senyawa-senyawa anti bakteri lain selain anti biotik.

b. Pencegahan Sekunder

Pencegahan sekunder dilakukan dengan melakukan pengobatan dan perawatan gigi dan mulut serta penambalan pada gigi berlubang.

c. Pencegahan Tersier

Pencegahan tersier dilakukan dengan cara perawatan pulpa (akar gigi) atau melakukan pencabutan gigi. Selain itu beberapa teknik pemeliharaan kesehatan gigi dan mulut yang dapat dilaksanakan adalah dengan cara menggosok gigi sehabis makan dan sebelum tidur malam dengan langkah sebagai berikut :

1. Letakkan bulu sikat gigi pada permukaan gigi dekat tepi usi dengan posisi membentuk sudut 45․ Mulai menyikat gigi geraham atas atau gigi belakang di salah satu sisi mulut. Sikatlah dengan gerakan melingakar dari atas ke bawah selama sekitar 20 detik untuk setiap bagian

2. Sikat setiap bagian gigi, mulai dari bagian gigi yang biasa untuk mengunyah, gigi yang dekat bagian pipi dan lidah, pastikan semua bagian ggi sudah tersikat, sehingga semua plak dan sisa makanan yang menempel di gigi hilang

3. Untuk membersihkan pemukaan dalam gigi dalam posisi vertikal atau gunakan ujung kepala sikat gigi, lalu sikat dengan gerakan melingkar dari tepi gusi sampai atas gusi lakukan gerakan 2-3 kali sikatan gigi pada geraham bagian bawah.

4. Ubah pola menyikat gigi jika diperlukan.

5. Jika menyikat gigi dimulai dari geraham atas, maka sikatan akhir pada geraham bagian bawah

Received: 15 September 2020, Accepted : October 2020 - Jurnal Photon Vol.11 No.1

DOI : https://doi.org/10.37859/jp.v11i1.2145

PHOTON is licensed under a Creative Commons Attribution-ShareAlike 4.0 International License 
6. Jangan menyikat gigi terlalu keras atau terlalu memberi tekanan pada gigi karena akan menyakitkan gigi dan gusi.

7. Jangan menyikat gigi dengan gerakan yang lurus. ( Syanne, 2017)

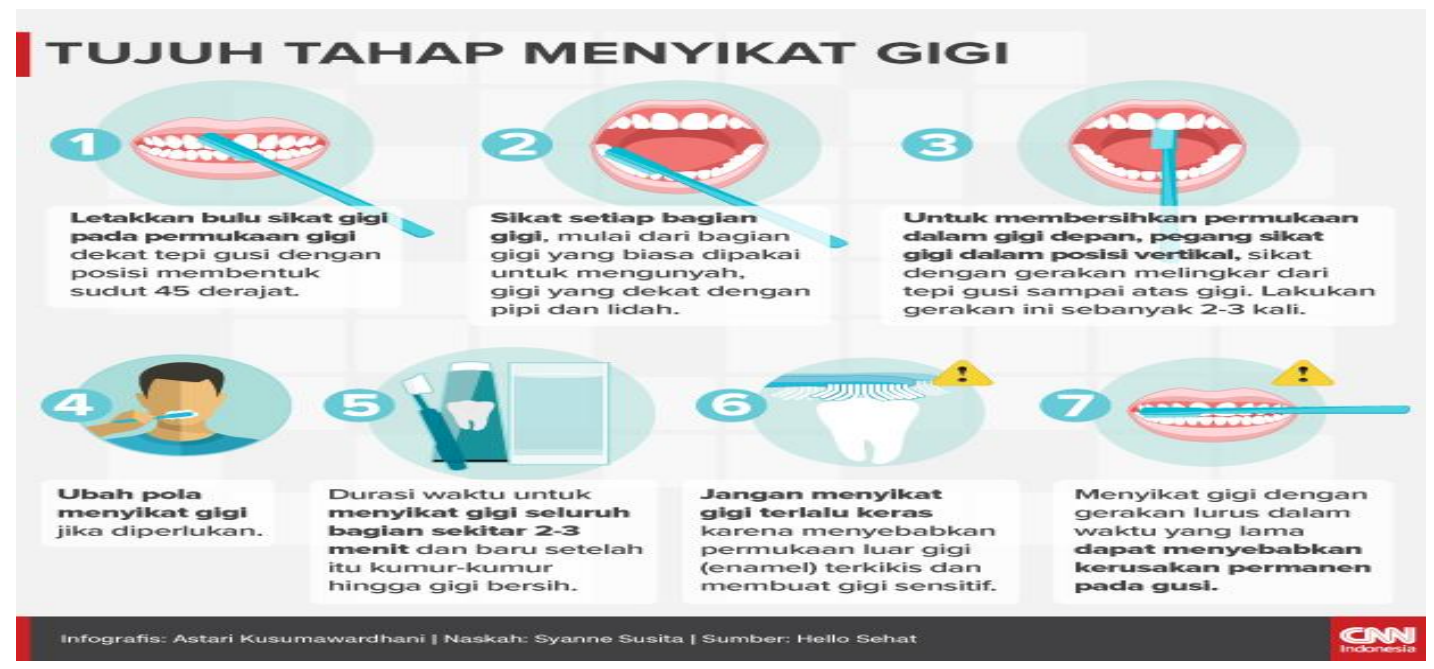

Gambar 2. Tujuh tahap menyikat gigi ( sumber : Susita Syanne, 2017)

\section{The Methods}

Desain penelitian yang digunakan dalam penelitian ini adalah metode deskriptif, yaitu menggambarkan peran orang tua dalam pencegahan karies gigi. Penelitian ini dilakukan di TK Aisyiyah 2 Pekanbaru dengan alasan karena adanya sampel yang memenuhi syarat dijadikan subjek penelitian, selain itu juga belum pernah dilakukan penelitian tentang pencegahan karies gigi pada anak pra sekolah.Populasi merupakan keseluruhan objek penelitian atau objek yangditeliti(Notoatmodjo,2010). Dalam penelitian ini yang menjadi populasi adalah semua orang tua murid TK Aisyiyah 2 Pekanbaru.yang berjumlah 70 orang. Sampel adalah objek yang diteliti dan dianggap mewakili seluruh populasi(Notoadmodjo,2010). Sampel dalam penelitian ini yaitu : 70 orang tua murid TK Aisyiyah 2 Pekanbaru.Teknik pengambilan sampel yaitu total sampling dimana cara pengambilan sampel dengan mengambil seluruh populasi untuk menjadi sampel (Ircham, 2009).

Dalam analisa data, peneliti menggunakan analisa univariate, yaitu analisa yang dilakukan terhadap variabel perilaku untuk mengetahui bagaimana peran orang tua dalam pencegahan karies gigi pada anak pra sekolah di TK Aisyiyah 2 Pekanbaru. Menurut Sudijono (2009), dengan melihat presentase data yang dikumpulkan dan sajian dalam bentuk tabel frekuensi dan dipersentasikan dari tiap variable. Sedangkan hasil perhitungan

Received: 15 September 2020, Accepted : October 2020 - Jurnal Photon Vol.11 No.1

DOI : https://doi.org/10.37859/jp.v11i1.2145

PHOTON is licensed under a Creative Commons Attribution-ShareAlike 4.0 International License 
persentase diolah menggunakan SPSS dan dimasukkan ke dalam hitungan mean/median dengan standar objektif sebagai berikut : BaikNilai >Mean, kurang baik: Nilai < Mean

\section{Result and Discussion}

Berdasarkan penelitian yang dilakukan di TK Aisyiah 2 Pekanbaru, dapat diperoleh data-data yang tergambar di tabel 1 dan 2 mengenai Deskripsi Peran Orang Tua dalam Pencegahan Karies Gigi sebagai berikut:

Tabel 1. Kategori, Frekuensi dan Presentase Responden

\begin{tabular}{|c|c|c|c|}
\hline No & Kategori & Frekuensi & Persentase (\%) \\
\hline $\mathbf{A}$ & Umur & & \\
\hline 1 & Dewasa Awal (26-35) & 62 & 96.88 \\
\hline 2 & Dewasa Akhir (36-45) & 2 & 3.12 \\
\hline $\mathbf{B}$ & Jenis Kelamin & & \\
\hline 1 & Laki-laki & 23 & 35,9 \\
\hline 2 & Perempuan & 41 & 64,1 \\
\hline $\mathbf{C}$ & Pendidikan & & \\
\hline 1 & Pendidikan Dasar (SD-SMP) & 0 & 0 \\
\hline 2 & Pendidikan Menengah (SMA/SMK) & 47 & 73.44 \\
\hline 3 & Pendidikan Tinggi ( D1 ke atas) & 17 & 26.56 \\
\hline $\mathbf{D}$ & Pekerjaan & $\mathbf{f}$ & (\%) \\
\hline 1 & IRT & 25 & 39,1 \\
\hline 2 & Swasta & 15 & 23,4 \\
\hline 3 & Guru & 19 & 29,7 \\
\hline 4 & PNS & 5 & 7,8 \\
\hline
\end{tabular}

Received: 15 September 2020, Accepted : October 2020 - Jurnal Photon Vol.11 No.1

DOI : https://doi.org/10.37859/jp.v11i1.2145

PHOTON is licensed under a Creative Commons Attribution-ShareAlike 4.0 International License 
Tabel 2. Hasil

\begin{tabular}{lllcc}
\hline No & & Memberi contoh & Frekuensi & Persentase \\
& & (f) & (\%) \\
\hline 1 & Baik & & 24 & 37.5 \\
2 & Kurang baik & & 40 & 62.5 \\
\hline & & Total & $\mathbf{6 4}$ & $\mathbf{1 0 0}$ \\
\hline
\end{tabular}

Mayoritas peran orangtua terhadap pencegahan karies pada anak usia pra sekolah pada kategori tidak baik sebesar $62.5 \%$. terdapat 40 responden yang memiliki peran yang tidak baik dalam melakukan pencegahan terjadinya karies gigi pada anak usia pra sekolah.Menurut asumsi peneliti hal di atas dapat dipengaruhi oleh beberapa faktor antara lain faktor tingkat pendidikan dan pekerjaan responden. tingkat pendidikan responden mayoritas adalah pendidikan menengah sebanyak 47 orang (73.44\%) dan sebanyak 33 responden (51.56\%) responden tidak bekerja.

Berdasarkan hasil wawancara peneliti beberapa responden mengatakan rata rata orangua kurang memperhatikan peran untuk mencegah terjadinya karies karena orangtua beranggapan bahwa gigi yang saat ini tumbuh masih berupa gigi susu dan akan berganti setelah gigi tersebut lepas. Dengan demikian orangtua mengatakan kalau terjadi caries tidak perlu dikhawatirkan karena yang akan datang gigi tersebut akan berganti dengan gigi yang baru.Hasil penelitian di atas hampir sama dengan hasil penelitian Darsini (2014) dengan judul pengaruh peran orangtua tentang perawatan gigi terhadap terjadinya caries dentis pada anak pra sekolah memperoleh hasil banyak orangtua yang tidak berperan daam perawatan gigi pada anak sebanyak $93.55 \%$.

Meskipun salah satu dugaan peneliti yang mempengaruhi peran orangtua dalam melakukan pencegahan karies adalah tingkat pendidikan yang mayoritas tingkat menengah. Tingkat pendidikan yang kurang dapat menghambat perkembangan sikap seseorang terhadap nilai baru sehingga informasi yang diterima juga semakin sedikit tentang bagaimana orangtua brperan untuk mendukung perkembangan anak (Suciari, Dkk, 2015).Menurut Nursalam (2003) dalam Suciari, dkk (2015) menyatakan bahwa semakin tinggi tingkat pendidikan seseorang akan semakin mudah menerima informasi dari luar tentang cara bagaimana mendukung perkembangan anak. Namun menurut peneliti hal tersebut bukanlah hal yang menjadi faktor penyebab tidak baiknya peran responden. Perlu ditekankan bahwa seseorang yang berpendidikan rendah belum tentu berpendidikan rendah pula. Pengetahuan tidak mutlak di peroleh dari pendidikan formal saja, akan tetapi juga dapat diperoleh pada pendidikan non formal. Dalam hal ini diharapkan kepada responden

Received: 15 September 2020, Accepted : October 2020 - Jurnal Photon Vol.11 No.1

DOI : https://doi.org/10.37859/jp.v11i1.2145

PHOTON is licensed under a Creative Commons Attribution-ShareAlike 4.0 International License 
agar lebih rajin mencari informasi tentang kesehatan khususnya tentang perawatan gigi untuk mencgah karies gigi pada anak baik dari tenaga kesehatan, maupun dari sumber informasi lainnya sehingga dapat menambah wawasan orangtua tentang perawatan gigi serta manfaat upaya pencegahan karies gigi agar derajat kesehatan gigi anak meningkat. Selain tingkat pendidikan responden, pekerjaan juga merupakan salah satu faktor yang menjadi salah satu penyebab tidak baiknya peran orangtua terhadap pencegahan karies gigi pada anak. Hasil penelitian menunjukkan 33 orang responden (51.56\%) tidak bekerja dan hanya sebagai ibu rumah tangga yang melakukan aktivitas di rumah . tetapi, hasil penelitian di atas tidak sesuai dengan hasil penelitian Putri Pratama dkk (2012) dengan judul penelitian perbedaan hubungan antara ibu bekerja dan ibu rumah tangga terhadap tumbuh kembang anak usia 2-5 tahun yang memperlihatkan hasil tidak ada hubungan dengan nilai $\mathrm{P}$ value=0,172. Hasil penelitian tersebut menunjukkan bahwa meskipun ibu yang bekerja lebih sedikit memiliki waktu luang dengan anak, namun tumbuh kembang anak sama dengan anak dari ibu yang tidak bekerja.

Ibu sebagai salah satu faktor lingkungan keluarga yang berpengaruh terhadap tumbuh kembang anak, memainkan peran dalam mendidik anak, terutama pada masa balita. Ibu sebagai model atau teladan yang akan ditiru oleh anaksebagai stimulasi perkembangan maupun kebiasaan anak dalam melakukan aktivitas sehari-hari (noor. SR, 2002 dalam Putri Pratama (2012).

Dengan demikian peneliti berpendapat bahwa ibu yang tidak bekerja seharusnya banyak memiliki waktu luang untuk mencari informasi tentang kesehatan maupun melakukan kegiatan untuk berperan mencegah terjadinya karies gigi pada anak. Diharapkan ibu yang tidak bekerja untuk banyak bergaul dengan orang lain untuk lebih banyak mendiskusikan tentang masalah kesehatan dan mencari jalan keluar dan bersama sama mencari informasi baik dari media cetak ataupun dari internet yang tersedia di handpone ibu rumah tangga.

\section{Conclusion}

Berdasarkan hasil penelitian yang telah dilaksanakan peneliti dengan cara membagikan kuesioner berisikan 15 pertanyaan berhubungan dengan masalah diteliti Pean orang tua dalam pencegahan keries gigi, sesuai dengan tujuan akan dicapai pada penelitian ini, maka dapat disimpulkan bahwa "Peran orangtua dalam pencegahankaries gigi pada anak usia prasekolah (3-5 tahun) di TK Aisyiyah 2 Pekanbaru tahun 2018" dalam kategori baik sebanyak 40 responden (62,5\%) dan kategori tidak baik sebanyak 24 responden $(37,5 \%)$.

Diharapkan kepada peneliti selanjutnya untuk melanjutkan peneliti ini agar peneliti yang telah ada menjadi sempurna, dan tidak terbatas pada perilaku saja, namun juga melibatkan sikap, dan supaya menggunakan waktu yang disediakan dengan sebaik-baiknya sehingga penelitian dapat cepat terselesaikan.Hasil penelitian ini sebagai informasi bagi sekolah TK Aisyiyah 2 Pekanbaru bagaimana peran orang tua dalam melakukan pencegahan karies gigi ada anak usia pra sekolah sehingga dapat di jadikan sebagai masukan bagi TK

Received: 15 September 2020, Accepted : October 2020 - Jurnal Photon Vol.11 No.1

DOI : https://doi.org/10.37859/jp.v11i1.2145

PHOTON is licensed under a Creative Commons Attribution-ShareAlike 4.0 International License 
Aisyiyah 2 Pekanbaru untuk meningkatkan pendidikan kesehatan tentang karies dan pencegahannya pada orang tua murid TK Aisyiyah 2 Pekanbaru. Dan untuk wali murid Memberikan contoh cara menyikat gigi dengan benar,Mengajak anak untuk menyikat gigi dan Sealu memberi tahu anak apa yang di lakukan setelah makan sarapan dan sebelum tidur

\section{References}

Hongini Yundli Siti dan Aditiawan,S,H,Hum (2012) Kesehatan Gigi dan Mulut; Buku lanjutan dental Terminologi. Bandung Pustaka Reka Cipta

Khotomi Azkiatul (2011). Gigiku sehat. terawat. Jakata: PT Sunda Kelapa Pustaka

Mardani (2016) Pengertian anak pra sekolah dan klasifikasi usia anak

Murdani.F (2016). Faktor factor yang mempengaruhi enuresis pada anak usia prasekolah. Skripsi tidak diterbitkan. Prodi D III Keperawatan UMRI. Pekanbaru

Nursalam (2003) dalam Suciari (2015) Semakin tinggi tingkat pendidikan maka semakin mudah menerima informasi

Noor 2002 dalam Pratama (2012) ibu sebagai salah satu faktor lingkungan keluarga yang berperan terhadap tumbuh kembah anak

Notoatmodjo (2010) objek penelitian atau objek yang dilakukan penelitian.

Rahma Utami. (2013). Penanamannilaikejujurananakdalamlingkunganmasyarakat di dusun1 dan dusun 2 Desa Teba Jawa Kabupaten Pesawaran. JurnalPendidikan

Riyanti E, (2012), Pengenalan Dan Perawatan Kesehatan Gigi Anak Sejak Dini, Available from:http://tugas2kuliah.wordpress.com. acessed 20 maret 2015

Roza dkk, Perilaku siswa tentang kesehatan gigi di sd negeri 005 gunung malelo koto kampar hulu tahun 2017(diakses September 2018)

Riskesdas. Riset Kesehatan Dasar, Laporan Nasional. (2013). Badan Penelitian dan pengembangan Kesehatan Republik Indonesia. Available from URL: http:// www.litbang.depkes.go.id/laporan RKD/ Indonesia/ Riskesdas 2013

Sariningsih. (2012). Merawat Gigi Anak Sejak Usia Dini. Jakarta: Elex Media.

W.J.SPoerwadar minta (2003). Kamus Umum Bahasa Indonesia. Balai Pustaka : (Jakarta)

Wong, D.L. (2003). Pedoman Klinis Keperawatan, alih bahasa Monika Ester editor edisi Bahasa Indonesia. Jakarta : EGC

Received: 15 September 2020, Accepted : October 2020 - Jurnal Photon Vol.11 No.1

DOI : https://doi.org/10.37859/jp.v11i1.2145

PHOTON is licensed under a Creative Commons Attribution-ShareAlike 4.0 International License 